\title{
Learning with Technologies
}

\author{
Madhu Pandey and Vivek Mishra* \\ Ram Yash P.G. College, Prayagraj, Uttar Pradesh, India \\ *Corresponding author: vivek_mishra@gmail.com
}

Received: 17 Oct., 2020

Revised: 27 Nov., 2020

Accepted: 10 Dec., 2020

\begin{abstract}
Placing students' learning requirements as the central focus of the work of a school was conceptualised almost half a century ago by John Dewey, and with the diffusion of various technologies into classrooms, notions of child-centred learning are being revisited. In the $21^{\text {st }}$ century, vendors are well aware that technologies such as the Internet and mobile phones are highly valued and fashionable to young people, and as such are very important to children's and young people's self-perceptions, identity and the practicalities of their lives.
\end{abstract}

Keywords: Technologies, Learning, mobile phones, vendors

Building innovation with technologies in school education is providing the opportunity to reconceptualise teaching and learning in the $21^{\text {st }}$ century. Inquiry-based, project-based and personalised learning pedagogies that include technologies aimed at building innovation capabilities in students.

A broad range of school activities are supported through an information technologies (IT) or a technological infrastructure, such as:

* teaching and learning in classrooms, in computer laboratories and at home (for example, through using computers and the Internet to support the use of interactive whiteboards; learning and content management systems; real-time, social learning software; virtual learning environments such as Second Life; and Web 2.0 applications)

* administration and record-keeping (for example, with databases that record students'

How to cite this article: Pandey, M. and Mishra, V. (2020). Inclusive Education. TechnoLearn: An International Journal of Educational Technology, 10(1\&2): 53-56. 
attendance, students' family background and contact details, student achievement outcomes, finance and asset management)

* information provision within and outside the school (for example, through online daily bulletins, newsletters and media releases)

* communication to teachers, students and parents (for example, using email, SMS messaging or the announcements functions of learning management systems)

* simulations and knowledge-building activities (for example, using Web 2.0 and Web 3.0 functionality)

* online content provision (for example, through the use of publicly and privately developed materials accessible over the Internet such as learning objects and online books)

* borrowing books (for example, through the use of online school library services).

\section{Emerging Challenges}

Technologies offer educators and students alike opportunities for creating meaningful learning environments. Technologies enable different types of social interaction, provide ready access to information and can overcome some of the difficulties presented by time and space. Students can create new materials, artefacts and new knowledge with the media tools now available to them. These tools are constantly evolving as individuals and companies create and refine new software. Including technologies in teaching and learning requires a reconceptualisation of the curriculum and how it can be taught. Using technologies to simply replace blackboards with whiteboards and pens with computers and word processors does not constitute a reconceptualisation of teaching and learning, nor the nature of school education. Such an approach will not support students to 'learn, unlearn, and relearn'.

\section{Defining Innovation}

Dictionaries define 'innovation' as 'introducing something new': the Latin stem 'innovare' refers to altering or renewing, and is derived from 'novus', meaning 'new' (Little, Onions \& Friedrichsen, 1973). That is, an innovation is something that is new, is positively different, or is better than what was there before. Innovations however, do not exist objectively or in an unchanging sense. Concepts of newness or reformation are viewed differently by different people, and to categorise something new as 'innovative' places additional meaning on its value or relevance. As such, to be 'innovative' is an affirmative description of an artefact or a process. While encouraging students to be creative involves encouraging them to use their imaginations and to be innovative, it also involves teachers and students learning how to constructively learn from making mistakes. Building innovation and creativity requires educators to move beyond rewarding students for providing correct answers to problems, to also rewarding 
them for their effort and ideas. This requires the processes of learning to be valued as well as the outcomes.

\section{Building Innovation and the Role of Schools}

Integrating technologies into teaching and learning is seen by many educators as affording opportunities to shift from teacher-centred to student-centred learning. Placing students' learning requirements as the central focus of the work of a school was conceptualised almost half a century ago by John Dewey, and with the diffusion of various technologies into classrooms, notions of child-centred learning are being revisited. In the $21^{\text {st }}$ century, vendors are well aware that technologies such as the Internet and mobile phones are highly valued and fashionable to young people, and as such are very important to children's and young people's self-perceptions, identity and the practicalities of their lives.

\section{Linking Discipline Knowledge and General Capabilities}

What the interactions between discipline knowledge and general capabilities mean for classroom practices requires further discussion. Solving problems, for example, does not happen in isolation from a body of knowledge of some kind, and often that knowledge-base is interdisciplinary. It is essential that educators understand and are able to articulate what constitutes capabilities such as ICT, creativity and innovation, and how discipline knowledge, general capabilities and cross-curriculum perspectives intersect and can be developed across discipline boundaries. Without such understandings, educators will not appreciate what is required of them. Without these understandings, the types of learnings espoused in the policies, which aim to enable students to meet the emerging challenges of the $21^{\text {st }}$ century, will not be achieved. In such circumstances, educators again will face the criticisms about their failure to appropriately prepare students for the likely futures they face. Students have to learn that critical and analytical thinking in one discipline of knowledge may not operate in the same way as in another discipline. Students now have to learn how to move rapidly from being a generalist to a specialist, and this requires the development of their research capabilities and their abilities to check the veracity of information. Technologies can assist students to creatively and productively learn knowledge-building practices. For example, students can learn creativity and knowledge-building strategies by being involved in social interactions that engage them in multiple processes.

\section{Educating for the Future}

Schools must create learning environments that encourage both teachers and students to experiment with ideas. Teaching students to be able to analyse and question information available to them across the disciplines is a capability that will be of value to students beyond 
P

Pandey and Mishra

schools. Inquiry-based, project-based and problem-based learning are approaches that use information processing to support students' learning about issues of meaning and relevance to them. These approaches fit well with technology-rich learning environments that focus on the learning experiences rather than the technologies. These approaches are appropriate both for personalised learning and for group work. The focus of such learning environments is on the students' excitement about solving problems or investigating an issue that is of interest to them. In these environments the focus is on the learning and the inclusion of technologies in ways that support students to achieve their learning objectives.

Inquiry-based learning and similar approaches can be used to support students to respond to problems in their immediate environs, by encouraging experimentation with the potential solutions and through using technologies to assist in predictions as well as background research. Software applications can be used as tools to support students' inquiries by assisting them to organise ideas, to search for current information, to prepare background papers.

\section{CONCLUSION}

The ubiquity of several technologies, and the robustness of young people's abilities to communicate and collaborate, presents challenges for educators and stakeholders about how they conceive of schools. Indeed, it is time to reconsider what is a school and in what ways it can best fulfil its roles. As children and young people are communicating with each other in online settings, the importance of learning in face-to-face settings is highlighted. Attendance at school brings young people physically together into social situations, and it is here they learn how to play games in real time and space, how to get on with others and how to resolve disputes. Through face-to-face learning, and through discussions with their peers, as well as by using the Internet, it is possible for young people to discover information, to clarify meanings and to create new ideas, both in real-time settings and online.

\section{REFERENCES}

Apple, M. 2001. Educating the 'right' way: Markets, standards, God and inequality. New York \& London: Routledge Falmer Press.

Beder, S. 2009. This little kiddy went to market: The corporate capture of childhood. Sydney: UNSW Press.

Fisher, K. 2007. Space and place: Learning environments for the ne $(x)$ t generation. Teacher, The National Education Magazine, 8 October, 4-6.

Taylor, S., Rizvi, F., Lingard, B. and Henry, M. 1997. Educational policy and the politics of change. London \& New York, Routledge. 